DOI: $10.15290 /$ bsl.2019.15.04

\author{
Agnieszka Czyżak \\ Instytut Filologii Polskiej \\ Uniwersytet im. Adama Mickiewicza w Poznaniu \\ e-mail: agaczyz@amu.edu.pl \\ ORCID: 0000-0001-8918-5264
}

\title{
To (jedyne) miejsce, tamte (najważniejsze) emocje - kilka uwag o twórczości Amosa Oza
}

W zakończeniu esejów wydanych przez Amosa Oza u kresu życia, a zatytułowanych Do fanatyków, pada wyznanie: „Kocham Izrael, nawet wtedy, gdy nie mogę go ścierpieć. Jeżeli jest mi sądzone upaść któregoś dnia na ulicy, chcę, by to się stało w Izraelu. Nie w Londynie, nie w Paryżu, Berlinie ani Nowym Jorku"1. Śmierć - zbliżająca się i spodziewana - miałaby tym samym być zwieńczeniem życia związanego z jednym, wyjątkowym miejscem na ziemi. Ambiwalencja uczuć przezeń wywoływanych to $\mathrm{w}$ istocie nieustanne ścieranie się gwałtownych i biegunowo sprzecznych emocji. Oz dodaje:

Lękam się bardzo o przyszłość [...]. Boję się fanatyzmu i przemocy, które coraz bardziej się u nas panoszą, i również za nie mi wstyd. Ale dobrze mi być Izraelczykiem. Dobrze mi być obywatelem państwa, w którym żyje osiem i pół miliona premierów, osiem i pół miliona proroków, osiem i pół miliona mesjaszy ${ }^{2}$.

Wstyd, uznawany przez wielu badaczy za jeden z najsilniejszych afektów3 ${ }^{3}$ a wywoływany $\mathrm{w}$ świadomości twórcy przede wszystkim przez współcze-

\footnotetext{
1 A. Oz, Do fanatyków. Trzy refleksje, przeł. L. Kwiatkowski, Poznań 2018, s. 133-134.

2 Tamże, s. 134.

3 Zob. S. Ahmed, Wstyd w obliczu innych, przeł. J. Misun, „Teksty Drugie” 2016, nr 4. Badaczka stwierdza m.in.: „Udręka wstydu wzmaga się, gdy inni widzą ją właśnie jako wstyd. Sama fizyczność wstydu - jak wstyd działa na ciała i przez nie - oznacza również, że wstyd
} 
sne przemiany w politycznych i społecznych działaniach jego własnego kraju (państwa, społeczeństwa), nie jest mimo wszystko w stanie stłumić głęboko odczuwanej, rosnącej przez całe życie, a ponadto wielorako ujawnianej w tekstach, miłości do ojczystej ziemi.

Amos Oz, zmarły 28 grudnia 2018, nie otrzyma już nagrody Nobla, choć przez lata był wymieniany jako jeden z kandydatów do jej uzyskania ${ }^{4}$. Twórca, uznawany przez wielu za najwybitniejszego pisarza izraelskiego, bywa też określany pisarzem jednego tematu, poruszanego często wprost, ale i stanowiącego podskórną tkankę tekstów. Tematem tym jest właśnie powstawanie państwa Izrael, jego kształtowanie się i rozwój, zmienne koleje losu, a przede wszystkim rozgrywające się na tle wielkich dziejów historie ludzkie, zawsze organicznie z nimi powiązane. Autor, jego narratorzy i bohaterowie - w powieściach, powiastkach dydaktycznych czy esejach - odkrywają swą trudną i skomplikowaną więź ze skrawkiem ziemi, który uznają za własny.

Wielu pisarzy izraelskich odsłaniało rozliczne problemy istniejące (nieuchronnie) w sferze relacji jednostki i wspólnoty z przestrzenią „darowaną do życia". Miriam Akavia, urodzona w Polsce pisarka, która tuż po wojnie, jako nastolatka zamieszkała w Izraelu, twierdziła na przykład z goryczą:

Większość narodów głosowała za prawem Żydów do własnego państwa, do małego kraju na zapomnianej, opuszczonej i zaniedbanej ziemi, która jak tylko odżyła, stała się od razu miejscem starć i sporów. Nie mamy szczęścia ${ }^{5}$.

Miejsce podarowane przez innych, a zarazem uznawane od tysiącleci za kolebkę wspólnotowego trwania, później obronione/wywalczone w kolejnych bojach, budzić musi silne, choć zazwyczaj ambiwalentne emocje. Patriotyzm

\footnotetext{
zakłada również de-formowanie i re-formowanie cielesnych i społecznych przestrzeni, ponieważ ciała «odwracają się» od innych, którzy są świadkami wstydu. [...] Zawstydzone wycofanie w siebie jest jednocześnie odwracaniem się od siebie. Być może ostatecznie nie ma gdzie się zwrócić" [tamże, s. 197]. W bolesnym, psychosomatycznym przeżywaniu wstydu niezwykle istotne okazują się zarówno podlegające deformacjom relacje z innymi, jak i konieczność ciągłego rekonstruowania rozpadającej się przestrzeni życiowej - takie doświadczenia często stają się udziałem bohaterów prozy Amosa Oza.

4 Amos Oz urodził się w Jerozolimie 4 maja 1939 roku.

${ }^{5}$ M. Akavia, Moje powroty, Kraków 2005, s. 169. W książce pisarka zamieściła więcej podobnych, pełnych emocji refleksji na temat przestrzennych uwarunkowań codziennego życia, postrzeganych jako szczególny rodzaj uwięzienia: „My, Izraelczycy, mamy kompleks ludzi, którzy długi czas pozbawieni byli wolności, a i teraz są jakby zamknięci. Na pewno dlatego tak bardzo lubimy podróżować. Lubimy wsiąść do samolotu (pociągiem nie możemy wyjechać z naszego kraju) i wyfrunąć z naładowanego dynamitem rejonu w szeroki wolny świat. Lubimy odetchnąć innym powietrzem i odczuć wielkie przestrzenie. Na krótki czas zapomnieć o morzu nienawiści, które nas otacza. Być na równi z innymi, być jednymi z wielu" [tamże, s. 243-244].
} 
natomiast pojmowany jako umiłowanie ojczystej ziemi - niedawno odzyskanej, wciąż oswajanej, nieraz odczuwanej jako specyficznie obca - staje się w takim przypadku szczególnie trudnym wyzwaniem, któremu należy sprostać, i zadaniem, które trzeba wciąż od nowa wypełniać.

Autobiograficzna opowieść Amosa Oza z roku 2002, zatytułowana Opowieść o miłości i mroku, to nie tyle zapis przebiegu życiorysowych doświadczeń, ile ich dokonana na starość interpretacja. Twórca w autotematycznych fragmentach wyrażał swoje najgłębsze przekonanie, że zbiór egzystencjalnych przeżyć pozostaje materią, którą można wielorako kształtować, dzielić, i ponownie łączyć, nasycać cudzymi wspomnieniami czy tworami wyobraźni. Odbiorca z kolei, traktowany jako podmiot czujący, bywał nakłaniany, czy wręcz zmuszany, do emocjonalnego zaangażowania. To szczególna, choć $\mathrm{w}$ istocie dość często spotykana, próba poszerzania spektrum oglądu historycznych wydarzeń poprzez nasycenie opowieści emocjonalnym przekazem. Jak podsumowywała Katarzyna Bojarska: „Afekty i emocje mają służyć przede wszystkim jako zapalnik głębokiego przeżycia i myśli ze względu na sposób, w jaki są w stanie nas pochwycić, zmusić do zaangażowania. Uczucie staje się katalizatorem dla wglądu krytycznego" ${ }^{6}$. Emocjonalny aspekt tekstów prowadzić ma ostatecznie ku „poruszaniu” do myślenia, a tym samym afektywna rama interpretacyjna może okazywać się szczególnie silnym impulsem przekształcania wiedzy o świecie.

W jednym z wywiadów z 2005 roku, zatytułowanym Kiedy wypłaczesz wszystkie łzy, Amos Oz tak mówił o swojej Opowieści:

Było mi bardzo trudno zawrzeć pokój z moimi rodzicami i z resztą rodziny, z Jerozolimą, w której się urodziłem i gdzie dorastałem. Jednak zrobiłem to jeszcze zanim zabrałem się do pisania tej książki - gdy stałem się wystarczająco stary, żeby zobaczyć moich rodziców w moich dzieciach. Gdy zacząłem pisać moje córki były mniej więcej w tym wieku, w jakim byli moi rodzice $\mathrm{w}$ tragicznym roku 1951, kiedy moja matka popełniła samobójstwo, a ojciec wszedł w swoją smugę cienia ${ }^{7}$.

Dlatego właśnie pisarz mógł patrzeć na swoich przodków jak rodzic na dzieci - bez złości, lecz „ze współczuciem, humorem, empatią, a przede wszystkim ciekawością"8. Tym samym nie próbował ustalić, kto jest winny tragicznym

\footnotetext{
${ }^{6}$ K. Bojarska, Sztuka, która krzywdzi? Granice gestu krytycznego wobec bolesnej pamięci (a cenzura), „Konteksty. Antropologia Kultury. Etnografia. Sztuka” 2013, nr 3, s. 116.

7 A. Oz, Kiedy wypłaczesz wszystkie łzy, rozm. M. Jędrysik, "Gazeta Wyborcza”, 27.05.2005, wyborcza.pl/1,75410,2733645.html [dostęp 26.05.2018].

8 Tamże.
} 
wydarzeniom sprzed wielu lat, ale dociekać na różne sposoby, w jaki sposób przeszłość kształtuje tożsamość człowieka.

Pokój z minionym czasem i ze zmarłymi został zawarty - dzięki temu Oz mógł uruchomić w utworze dwie splecione ze sobą perspektywy oglądu: patrzenie na rzeczywistość oczyma dziecka, dorastającego młodzieńca, wchodzącego w samodzielne życie człowieka oraz równorzędne wobec nich spoglądanie na przeszłe wydarzenia z pozycji starego pisarza, świadomego bliskości własnego kresu. Stale ujawniane napięcie pomiędzy naiwną, ufną akceptacją świata tłumaczonego dziecku przez rodziców zderzana jest w utworze z wiedzą (a przede wszystkim samowiedzą) zbudowaną na wielu dekadach samodzielnego dążenia do poznania reguł rządzących jednostkowym i zbiorowym trwaniem na ziemi.

Kluczowa dla biografii Oza samobójcza śmierć matki, rozłamująca czas i niszcząca bezpowrotnie dzieciństwo - dokładnie opisana w zakończeniu - zamyka Opowieść o miłości i mroku. Nieobecny nie tylko przy tragicznym wydarzeniu, ale i na pogrzebie matki twórca napisał po upływie pół wieku, odtwarzając skłębione, silne emocje, wzajemnie się wykluczające, a zarazem dopełniające:

Gdybym był wtedy przy niej [...] w sobotni wieczór, z pewnością próbowałbym wszelkimi sposobami przekonać ją, że nie wolno jej tego robić. A gdyby mi się nie udało, zrobiłbym wszystko, aby wzbudzić w niej litość, aby zlitowała się nad swoim jedynym dzieckiem. Płakałbym i błagał bez cienia wstydu, objąłbym ją za nogi, a może nawet udawałbym, że mdleję, albo biłbym się i drapał do krwi, tak jak widziałem, że ona robiła w chwilach rozpaczy. Albo rzuciłbym się na nią jak morderca, bez wahania chwyciłbym wazon i rozbił na jej głowie. Albo uderzyłbym ją żelazkiem, które stało na półce w kącie pokoju. Albo korzystając z jej słabości, rzuciłbym się na nią i związał jej ręce z tyłu, a potem porwałbym i zniszczył wszystkie jej pigułki, tabletki, pastylki, roztwory, ekstrakty i syropy. Ale nie było mi dane tam być 9 .

Emocje zrozpaczonego dziecka, pragnącego raczej skrzywdzić matkę, niż ją stracić, ujęte zostały w karby dojrzałej narracji, świadomej nieodwracalności strumienia czasu.

Matka bohatera poruszana do głębi kolejnymi strasznymi wieściami, jakie przywozili ocalali z Zagłady, przede wszystkim zaś wiedzą o tym, co stało się $\mathrm{w}$ jej rodzinnym Równem i okolicach, zaczęła izolować się od codziennego życia i tracić kontakt z ukochanym i kochającym synem. Beata Przymu-

\footnotetext{
9 A. Oz, Opowieść o miłości i mroku, przeł. L. Kwiatkowski, Poznań 2016, s. 653. Kolejne cytaty lokalizuję w tekście głównym, oznaczając je skrótem O.
} 
szała, w książce o emocjonalnych aspektach tekstów ofiar i ich dzieci, pisała: „Problem odbioru świadectw wskazuje na kwestię konieczności ich słuchania, ale także na niemożność przejścia przez to doświadczenie «bezkarnie», emocjonalne koszty bycia obok świadków bywają olbrzymie" ${ }^{10}$. Emocjonalna (a później faktyczna) nieobecność pośrednio dotkniętej traumą matki stała się ostatecznie bezpośrednią traumą dziecka. Specyficznie "dziedziczona” trauma drugiego pokolenia miała $\mathrm{w}$ tym przypadku wymiar zarazem najbardziej indywidualny, jak i ściśle zespolony z wspólnotowym życiem - dla przyszłego pisarza stała się punktem węzłowym biografii.

Istotą silnej więzi między bohaterem i matką (a po części też ojcem) było splątanie - tytułowych - miłości i mroku. Ciemność (niepokój, niepewność, lęk, brak wsparcia) istniała obok najszczerszych uczuć przywiązania, podziwu, potrzeby bliskości. Takie zawęźlenie emocji można uznać za specyficzną prefigurację sieci afektywnych połączeń z ojczyzną - oglądaną równocześnie z perspektywy budowanego przez lata dystansu oraz oczyma pełnego miłości i nadziei (naiwnego) dziecka. W oczach narratora Izrael jawić się może tym samym zarówno jako kraj wstrząsany wewnętrznymi konfliktami oraz skazany na nieustanne zewnętrzne zagrożenia, jak i miejsce najbardziej własne, jedyne na świecie.

Skomplikowane relacje między chłopcem a rodzicami - wedle starego już twórcy - niedojrzałymi nie tylko do roli ojca i matki, czy męża i żony, ale i budowniczych nowego państwa, stały się medium, które pozwoliło ukazać różnice mentalności pomiędzy pokoleniem przybyszów z różnych zakątków Europy a pokoleniem ich dzieci nieznających innej rzeczywistości niż kraj osiedlenia. Jednak Opowieść o miłości i mroku to także historia specyficznej substancjalizacji terytorium Izraela, nabierania przez wymarzone w snach przodków ziemie konkretnego kształtu, kolorytu, a przede wszystkim znaczeń.

Dla przyjeżdżających zewsząd marzycieli - takich jak rodzice bohatera - ziemie te bywały rozczarowaniem, smutnym, jałowym miejscem, zupełnie niepodobnym do tego z rojeń i pragnień. Dla urodzonych w Izraelu stawały

10 B. Przymuszała, Smugi Zagłady. Emocjonalne i konwencjonalne aspekty tekstów ofiar i ich dzieci, Poznań 2016, s. 336. Badaczka, przywołując koncepcję „psychicznej reprezentacji emocji” (stworzonej analogicznie do poznawczej reprezentacji świata zewnętrznego), przypomina, iż do jej tworzenia „używamy różnych kodów (obrazowego, opartego na cielesnych reakcjach, werbalnego, dotyczącego etykiet językowych i abstrakcyjnego, pozwalającego na pogłębione działania poznawcze)" [tamże, s. 27-28]. Istotne wydaje się rozróżnienie między kodowaniem językowym i abstrakcyjnym, bowiem w ramach pierwszego używa się utrwalonego zaplecza kulturowego, a w ramach drugiego dochodzi do twórczego przekształcania przeżyć, ich rozwijania i kontrolowania. 
się zadaniem do wypełnienia, projektem, który domagał się konkretyzacji $\mathrm{w}$ twórczym działaniu. Jednym z kluczowych wydarzeń $\mathrm{w}$ tym procesie okazał się ukazany przez Oza - w sposób niezwykły, poruszający i zapadający na długo w sferę emocji, a zatem i w pamięć - dzień 29 listopada 1947 roku, kiedy to na posiedzeniu Zgromadzenia Narodowego w Lake Success miano zdecydować o dalszym losie terenów na Bliskim Wschodzie, znajdujących się wówczas pod protektoratem brytyjskim. Większość dwóch trzecich głosów była potrzebna do przyjęcia wniosku, by na obszarze ówczesnego mandatu brytyjskiego ustanowiono dwa suwerenne państwa, żydowskie i arabskie, do czego ostatecznie nie doszło i - jak spekulują niektórzy - większość późniejszych konfliktów dotykających ten rejon świata wynikła z faktu, że na spornych terenach powstało tylko jedno państwo ${ }^{11}$.

$\mathrm{W}$ czasie transmitowanego przez radio głosowania w Jerozolimie była już noc, a mimo to wszyscy Żydzi czekali na ogłoszenie wyników. Oz opisuje ciszę, jaka zapadła po odczytaniu wszystkich głosów: „Po tych słowach głos momentalnie zamilkł. Nastała cisza jakby z innego świata i wszystko zamarło $\mathrm{w}$ bezruchu, przeraźliwa, złowroga cisza, milczenie wstrzymującego oddech tłumu, cisza, jakiej nie słyszałem nigdy w życiu, ani przed tamtą nocą, ani po niej" [O, s. 447]. Dławiące wszystkich, głuche milczenie najdobitniej świadczyło o sile targających zgromadzonymi afektów, wciąż jeszcze niemożliwych do przełożenia na język emocji.

Porażająca cisza trwała zresztą od początku zbiorowego oczekiwania na wyrok ONZ:

Jak w koszmarnym śnie wszyscy stali nieruchomo w żółtawym świetle latarni, stłoczeni i milczący, tworząc istny las cieni na naszym podwórku i u sąsiadów, na chodnikach, na jezdni, na balkonach, i w bladej poświacie wyglądali jak wielkie zgromadzenie duchów. Setki mężczyzn i kobiet stały w absolutnej ciszy: sąsiedzi, znajomi i obcy [O, s. 447].

Przybysze z różnych zakątków świata, pierwsi osadnicy i ocalali z Zagłady, niczym cienie, duchy - upiory przypominające o cywilizacyjnej katastrofie, która rozbiła podstawy znanego wcześniej świata - czekali na wyrok. Po słowach „propozycja przyjęta” głos spikera został zagłuszony przez wrzawę,

11 Po II wojnie światowej Europa - zwłaszcza środkowa i wschodnia - stała się miejscem wielu brutalnych wysiedleń, a także dobrowolnych migracji. Późniejsze szczelne zamknięcie granic sprawiło, że dla przesiedleńców nie istniała szansa na powrót w rodzinne strony. Jednak w świadomości ich potomków, po upływie lat od tragicznych wydarzeń, zatarta została pamięć o skomplikowanych procesach wykorzenienia i trudnej historii zamieszkiwanej przez nich ziemi - dla dzieci i wnuków migrantów stała się ich ziemią rodzinną, której dziejów $\mathrm{z}$ reguły nie mieli potrzeby weryfikować. 
która wybuchła nagle z całą mocą i połączyła odległe miejsca na dwóch kontynentach. Głos ten:

zatonął w dochodzącym z radia ryku żywiołowej radości, jaki wezbrał gwałtownie i niby lawa wylał się z galerii w Sali Zgromadzenia, a po kilku sekundach kiedy wszyscy stali $\mathrm{w}$ osłupieniu $\mathrm{w}$ jednej chwili również nasza spokojna ulica na obrzeżach północnej Jerozolimy rozbrzmiała przeraźliwym wrzaskiem, przenikającym ciemność, budynki i drzewa, wrzaskiem, który zagłuszał sam siebie [O, s. 447-448].

Nieartykułowany, „przeraźliwy wrzask” był wówczas jedyną możliwą reakcją na wieść o spełnieniu marzeń zarówno wspólnoty, dążącej do odnalezienia własnego miejsca na ziemi, jak i każdego z tam obecnych, $\mathrm{z}$ reguły obciążonych bagażem trudnych lub niemożliwych do wypowiedzenia doświadczeń.

Sięgający pamięcią do przeżyć dziecka $\mathrm{z}$ owego dnia, a zarazem świadomy wszelkich okoliczności tego zdarzenia pisarz, podkreślał metafizyczny, niezwykły wymiar owego wrzenia, pobrzmiewającego głosami także tych, którym nie dane było dotrzeć do Izraela:

nie był to okrzyk triumfalny - nie przypominał też wycia kibiców na stadionie czy świętującego tłumu - brzmiało to raczej jak okrzyk zgrozy i przerażenia, dramatyczny, kruszący skały i mrożący krew w żyłach krzyk, jak gdyby naraz wszyscy zmarli i ci, co dopiero zostaną zabici, zawołali przez niewidzialne okno, które otwarło się dla nich na mgnienie oka, by zaraz się zamknąć [O, s. 448].

Po chwili dopiero pojawiły się bardziej zwyczajne sposoby wyrażania radości - zabrzmiały oklaski i pieśni: Tu w kraju przodków, Lud Izraela żyje oraz hymn narodowy.

Pisarz wspominał też ówczesne zachowanie ojca, który wprawdzie nie umiał śpiewać, jednak nie stał w milczeniu, lecz krzyczał co sił, przeciągle jedną samogłoskę „ "a" - aż do utraty tchu, a kiedy kończyło mu się powietrze, brał głęboki oddech, jak tonący i krzyczał dalej. Mężczyzna, który pragnął zostać wybitnym profesorem - na co zresztą zdaniem syna zasługiwał - był wtedy jednym wielkim krzykiem, wówczas bowiem, ów skromny, cichy, pogodzony (jakoby) z losem człowiek, po raz pierwszy i jedyny w życiu pozwolił sobie na uzewnętrznienie targających nim uczuć. Tak też został zapamiętany przez dziecko, chłonące wówczas emocje tłumu, nasycające się poczuciem jedności, wspólnoty, więzi ze współbraćmi.

Powszechna radość nie mogła, co prawda, powstrzymać żadnego z następnych wydarzeń, kiedy w ciągu kilku miesięcy co setny z wiwatującego tłumu musiał zginąć w walce, była natomiast symbolicznym początkiem: 
rozochoceni uczestnicy tego karnawału wspinali się na brytyjskie wozy opancerzone i zatykali na nich flagi państwa, które wprawdzie jeszcze nie powstało, ale tej nocy tam, w Lake Success, zdecydowano, że wolno mu będzie powstać, co też miało nastąpić za sto sześćdziesiąt siedem dni i nocy [O, s. 450].

Emocje rozradowanego tłumu, burzące spokój owej nocy, zapadły w pamięć bohatera/autora i do końca stanowiły swoistą przeciwwagę dla krytycznego oglądu kolejnych zwrotów w izraelskiej historii walki o utrzymanie państwowości ${ }^{12}$.

W opowieści Oza w procesie substancjalizacji terytorium Izraela niezwykle ważny okazał się czynnik niematerialny, a jednak rudymentarny, czyli język. W specyficznej wielojęzycznej zbiorowości pionierów, uchodźców, uciekinierów, ocaleńców język nowohebrajski stał się niezwykle ważnym czynnikiem spajającym wspólnotę. $\mathrm{W}$ dodatku paradoksalnie dawał przewagę Synom nad Ojcami - jedna, wspólna dla wszystkich mowa zastąpiła podobne wieży Babel pomieszanie języków. Rodzice małego Amosa władający wspólnie kilkunastoma językami własnego syna uczyli tylko tego właśnie jednego języka. W esejach Do fanatyków Oz przyznawał z autoironią:

W czasach dzieciństwa $\mathrm{w}$ Jerozolimie sam też byłem małym syjonistyczno-nacjonalistycznym fanatykiem - żarliwym, zadufanym, otumanionym. Byłem ślepy na wszelką argumentację wykraczającą choć trochę poza żydowsko-syjonistyczną opowieść, jaką kładł nam do głowy cały niemal świat dorosłych ${ }^{13}$.

Wychowanie $\mathrm{w}$ duchu niekwestionowanego patriotyzmu, przeradzającego się nieraz w nacjonalizm, wspierane bywało emocjonalnym szantażem, nakazującym jednoznaczne opowiadanie się po stronie własnego narodu i cudem (od)zyskanego państwa.

Po wielu latach, kiedy dystans wobec minionych wydarzeń został ukształtowany zarówno przez kolejne doświadczenia w życiu osobistym, jak i przemiany $w$ funkcjonowaniu państwa oraz zamieszkującej je zbiorowości, pisarz zaczął przychylać się do wizji połowicznej, a więc kontrolowanej przynależności do wspólnoty. Stwierdzał jednoznacznie:

Wszyscy jesteśmy w połowie połączeni z kontynentem, którym jest rodzina, język, społeczeństwo, wierzenia i przekonania, państwo, naród [...]. Lepiej dla

12 W tym miejscu należy przypomnieć, iż pisarz brał udział jako żołnierz w wojnie sześciodniowej w 1967 roku oraz w wojnie Jom Kipur w 1973 - obowiązek obrony granic był dla niego wówczas powinnością, którą należało spełnić bez wahania.

13 A. Oz, Do fanatyków, s. 15. 
nas, żebyśmy pozostali półwyspami. To chyba dla nas odpowiednie. Są na świecie religie, ruchy ideologiczne i polityczne, które pchają każdego z nas, byśmy się bez reszty zatopili $\mathrm{w}$ zbiorowości, rezygnując $\mathrm{z}$ bycia półwyspem, stając się zaledwie drobnym ziarenkiem, molekułą w bryle narodu, wiary, ruchu ${ }^{14}$.

Wiara w wartość jednostkowego istnienia, połączonego z życiem wspólnoty, a jednak wobec niego odrębnego, doprowadziła Oza do jednoznacznego oporu wobec fanatyzmów wszelkiego rodzaju i proweniencji.

Podobnie rzecz się ma w filmowej adaptacji głównych wątków książki - powstała w roku 2015 ekranizacja Opowieści o miłości i mroku ukazuje niebezpieczeństwa tkwiące $\mathrm{w}$ zbytnim zawierzeniu wspólnotowym ufundowaniom egzystencji ${ }^{15}$. Nie wdając się $\mathrm{w}$ analizowanie słabości filmu czy braku doświadczenia debiutującej reżyserki, stwierdzić trzeba, że wybór języka hebrajskiego, w którym został zrealizowany wydaje się ze wszech miar słuszny - pozwala lepiej przybliżyć ówczesne jerozolimskie realia oraz wejrzeć w głąb minionego czasu. Do historii tragicznego dzieciństwa splecionej $\mathrm{z}$ obrazami rodzącego się państwa, tak bardzo związanej z konkretnym miejscem i czasem, reżyserka Natalie Portman starała się dołączyć uniwersalny wymiar opowieści o narodzinach twórczej wrażliwości i wspólnotowej odpowiedzialności. A jednak film pozostaje przede wszystkim współczesną "translacją" biograficznych doświadczeń, głęboko osadzonych w izraelskich dziejach - podobnie jak w tekście, niezwykle ważnym wydarzeniem okazuje się dziecięca „bratobójcza” zbrodnia i wina. Mały Amos podczas urodzinowego przyjęcia, niechcący spowodował wypadek, w którym okaleczony został młodszy brat jego arabskiej towarzyszki zabaw. Z perspektywy późniejszych dziejów konfliktu, to jednak nie tragiczne konsekwencje owego wypadku, ale właśnie rezolucja z Lake Success ostatecznie uniemożliwiła wszelki kontakt z dziewczynką, z którą w innych okolicznościach historycznych i politycznych z pewnością mógłby się zaprzyjaźnić.

Dorosłe życie bohatera ukazane zostało jedynie w kilku ujęciach w zakończeniu filmu - kiedy to młodemu człowiekowi mieszkającemu i pracującemu w kibucu, udało się (przynajmniej po części) zbliżyć się do ideału mężczyzny, patrioty i Żyda, ideału wyśnionego przez matkę w latach niepowodzeń i zwątpienia. Choć - jak twierdzi narrator autobiograficznych wynurzeń - przede wszystkim udało mu się stworzyć zewnętrzny jego pozór, łatwy do odkrycia przez „zdolniejszych” adeptów nowych idei.

14 Tamże, s. 45.

15 Opowieść o miłości i mroku, reż. N. Portman, Izrael, 2015. 
Substancjalizacja terytorium państwa tworzonego z mozołem dokonywała się w dużej mierze dzięki kibucom i ich mieszkańcom, z poświęceniem przekształcającym pustynną i jałową przestrzeń $w$ tereny uprawne, a jednocześnie poddającym się surowym regułom zbiorowego życia codziennego. Pisarz, ukazując wizję obranego wówczas modelu wspólnotowego trwania, nie wahał się przed piętnowaniem jego poszczególnych realizacji - i to na każdym etapie twórczości. Bohaterowie Oza przechodzili zazwyczaj trudną drogę, zanim mogli osiągnąć, choćby częściową, harmonię ze światem, w którym przyszło im żyć. W powieści Spokój doskonały z roku 1982, tytułowy spokój bohater zyskał dopiero po kolejnych próbach ucieczki z trudnego do oswojenia miejsca. Kameralna historia małżeńska ukazuje zresztą problem w szerszym wymiarze - jak podkreślała Justyna Sobolewska:

opowiada również o konflikcie pokoleń, pionierów i ich dzieci, ale także o kraju zarażonym nienawiścią, w którym siłą napędową jest chęć wyrżnięcia wrogów. „To przepastne bagno, a nie państwo. Dżungla a nie kibuc. Śmierć a nie syjonizm" - mówi gorzko Azaria premierowi, który ich odwiedził ${ }^{16}$.

Słowa gniewnej krytyki systemu, wypowiedziane przez jednego z mieszkańców kibucu w obecności przedstawiciela rządzących, wyraziście ukazują rozziew między ideą a jej konkretnymi próbami wcielenia w życie.

Dla Amosa Oza niezwykle ważny okazywał się obowiązek (przymus?) rejestrowania różnic między abstrakcyjną wizją a dojmująco uciążliwą codziennością. A mimo to twórca pozostał nie tyle kronikarzem niedostatków, potknięć i trudności w dziejach tworzącego się nowego narodu, ile wizjonerem potrafiącym przeciwstawić się pokusie wyboru innych, prostszych, jednoznacznych ocen, a więc łatwiejszych, jak by się zdawało, podsumowań historii zbiorowej. Agata Bielik Robson podkreślała: „Żaden inny pisarz żydowski - czy raczej izraelski - nie dokonał tak wiele, by zdekonstruować wszelkie przesądy dotyczące wyższości diaspory"17. W jego ujęciu bowiem to właśnie nieustępliwe, choć często okupione bólem, trwanie na otrzymanym skrawku ziemi dowodzi rzeczywistej zdolności poświęcenia się $\mathrm{w}$ imię wspólnoty. Badaczka, próbując dociec istoty wyborów światopoglądowych Oza, przywołała też przeciwne im przeświadczenia, obecne między innymi w pismach Erica Hobsbawma ${ }^{18}$, wedle których Żydzi pozostający w diasporze przewyższają swoich przywiązanych do rodzimej ziemi pobratymców -

\footnotetext{
16 J. Sobolewska, Spokój między wojnami, „Polityka” 2010, nr 43, s. 94.

17 A. Bielik-Robson, Amos Oz: w poszukiwaniu mocy, Newsweek.pl, http://www.newsweek.pl/ europa/amos-oz-w-poszukiwaniu-mocy [dostęp 15.12.2017].

18 Eric Hobsbawm, urodzony w 1917 roku w rodzinie austriackich Żydów, po dojściu Hitlera do władzy wyjechał do Londynu, gdzie spędził resztę życia jako wykładowca na brytyjskich
} 
są jednostkami wybierającymi oświecenie ponad tradycję, a jako nośnicy uniwersalnego rozumu stają się chętnie kosmopolitami, odważnie inwestującymi $\mathrm{w}$ postęp i racjonalizację społeczeństwa.

Dla Amosa Oza natomiast od samego początku niezwykle istotny stał się problem kształtowania i tworzenia nowej narodowej tożsamości - bardziej konstruowanej niż rekonstruowanej. Jego powieści, a w szczególności autobiograficzne opus magnum, stanowią nie tylko kompendium wiedzy na temat losów Izraela od czasów osadnictwa w Palestynie po dzień dzisiejszy, ale są przede wszystkim traktatem „na temat mentalności Żydów, którzy w tym eksperymencie państwowotwórczym uczestniczyli, częściowo korzystając ze swego doświadczenia diasporycznego, częściowo zaś się z niego wyzwalając" ${ }^{19}$. W końcu trudniej było wspólnie trwać w ciasnej, otoczonej wrogim sąsiedztwem przestrzeni, niż uznać za nadrzędną wartość jednostkową wolność wyboru własnego miejsca w świecie.

Pisarz opowiadał $\mathrm{w}$ istocie o pokonywaniu mentalności diaspory, koniecznym, by powstało państwo Izrael. Świadomość proizraelska, do której zawsze przyznawał się autor, oraz dojrzały bohater napisanej przez niego Bildungsroman, nie była jednak $\mathrm{w}$ żadnym stopniu nacjonalizmem, zamkniętym na uniwersalne wymiary jednostkowej i wspólnotowej egzystencji. Bielik-Robson przypominała:

To nie przypadek, że Michael Walzer w swojej Interpretacji i krytyce społecznej właśnie Amosa Oza wybrał na patrona krytyki lojalnej, a więc takiej, która choć nie szczędzi gorzkich słów swojej wspólnocie, robi to zawsze $\mathrm{z}$ jej wnętrza, nie podważając samych podstaw, na jakich się ona opiera. I to nie przypadek, że Marks i natchnieni przezeń krytycy w rodzaju Hobsbawma stanowią dla Walzera wzorzec krytyki nielojalnej: przeprowadzonej z zewnątrz ${ }^{20}$.

Twórca, nieodmiennie czując się częścią wspólnoty, tworzył przede wszystkim dla niej. Pomimo tego, że wiele stron poświęcił grzechom syjonizmu, nadal pozostawał wierny samej idei, niepodważalnej, choć wypaczanej w ko-

\footnotetext{
(później też na amerykańskich) uniwersytetach. Jego ostatnią pracą naukową z 2011 roku była rozprawa Jak zmienić świat. Marks i marksizm 1840-2011.

19 A. Bielik-Robson, Amos Oz: w poszukiwaniu mocy. Badaczka, przeciwstawiając sobie krytyczne wobec wielu działań Izraela postawy Hobsbawma i Oza, starała się pokazać, że pierwszy $\mathrm{z}$ nich, pisząc $\mathrm{z}$ pozycji diasporycznej, usuwał $\mathrm{z}$ pola widzenia perspektywę bytowania $\mathrm{w}$ ciągłym zagrożeniu, natomiast drugi, patrząc $z$ wewnątrz, potrafi dostrzec realne (nieuchronne?) skutki takich warunków wspólnotowego życia.

20 Tamże. Być może spory tego rodzaju mają też wymiar pokoleniowy - Michael Walzer, autor fundamentalnych dla omawianej problematyki rozpraw O tolerancji (1997) czy Prawo, polityka i moralność w judaizmie (2006) urodził się w roku 1935.
} 
lejnych realizacjach, a ponadto niestrudzenie wierzył w wartość jednostkowo uprawomocnianego poczucia zakorzenienia i przynależności.

Amos Oz mówił w przywołanym wcześniej wywiadzie o intymnym, swoiście oczyszczającym charakterze aktu tworzenia:

To było jak zaproszenie zmarłych do domu, jak rozmowa przy obiedzie na tematy, o których nigdy nie mówiliśmy, kiedy byli żywi. Przedstawiłem ich sobie nawzajem - rodziców, moją żonę i dzieci, ale nie chciałem, żeby zmarli zamieszkali w moim domu. To była tylko wizyta. Nie chcę mieszkać wśród duchów ${ }^{21}$.

Rzecz bowiem nie w tym, by zaprzeczać istnieniu rodzinnych tragedii, lecz potrafić żyć bez ich destrukcyjnego wpływu. I podobnie: nie trzeba odrzucać trudnej pamięci o losach wielokulturowej diaspory, wystarczy być w stanie (choćby częściowo) wyzwolić się z jej ograniczeń.

Wielu twórców żydowskich uznawało za swe główne zadanie dokumentowanie doświadczeń rozproszonego narodu. Tymczasem $\mathrm{Oz}$ postawił przed sobą inny cel. W swoim późnym zbiorze opowiadań z roku 2012, zatytułowanym znamiennie Wśród swoich, znów powrócił do przeszłości, by pokazać jednostkowe drogi ku przekraczaniu nieuchronnie pojawiających się słabości, ku pokonywaniu nieodmiennie rodzących się wątpliwości, ku odrzucaniu oczywistych wahań czy chęci ucieczki. Kibuc pod koniec lat pięćdziesiątych ponownie stał się swoistą retortą, w której to, co pojedynczo (boleśnie) doświadczane zmieniało się $\mathrm{w}$ ufundowane wspólnotowo przekonanie o konieczności podejmowania zbiorowych wysiłków. Bohaterowie utworów wiedzą, że wybrana przez nich do życia, różnorako (a nawet nieznośnie) ograniczana przestrzeń dopiero za dziesięć, dwadzieścia lat stanie się spokojniejszym, własnym miejscem. Wiedzą także, że w rodzącej się społeczności „wszystkie sprężynki są napięte do granic, a cała maszyna jeszcze trzęsie się z wysiłku" 22. Kibuc Jikhat - miejsce akcji wszystkich zebranych w tomie opowieści - ukazany po upływie półwiecza nadal jest przestrzenią, w której jednostkowe emocje trzeba tłumić w imię nadrzędnego celu budowania nowej rzeczywistości. Można tylko podporządkować się obowiązującym regułom lub opuścić kibuc na zawsze ${ }^{23}$.

\footnotetext{
21 A. Oz, Kiedy wyptaczesz wszystkie łzy.

22 A. Oz, Wśród swoich, przeł. L. Kwiatkowski, Poznań 2016, s. 120.

23 Należy pamiętać, że w twórczości Oza ucieczka czy rezygnacja z udziału w „eksperymencie państwowotwórczym" nie jest klęską moralną. Umiejętność bycia "wśród swoich”, zdolność podporządkowania się zbiorowej wizji, uzależniona jest w każdym jednostkowym przypadku od wielu okoliczności zewnętrznych, od sumy życiowych doświadczeń oraz predyspozycji psychicznych. Niezbędna w takiej sytuacji specyficzna emocjonalna "równowaga" nie każdemu jest dana, a niewielu potrafi wypracować ją wbrew przeciwnościom losu i wewnętrznym uwarunkowaniom.
} 
Ukształtowani w innej rzeczywistości „,seniorzy”, przybyli z różnych krajów świata, muszą z mozołem tłumaczyć sobie konieczność poddania się rygorom, które dla ich potomków staną się warunkami niejako "naturalnymi”. Ruta Pragier w tekście poświęconym twórczości Oza rekonstruowała ówczesne założenia wspólnotowych idei jako walkę między wizjami autoidentyfikacyjnymi. W takim ujęciu nowy naród kształtował się poprzez budowanie opozycji wobec tradycyjnych obrazów. Obywatel rodzącego się państwa musiał być przede wszystkim silny - należało bowiem na zawsze rozstać się z obrazem (czy raczej stereotypem) „europejskiego" Żyda, niesprawnego fizycznie, lękliwego słabeusza, godzącego się na poniżanie i pogardę. Hasło "Nasi synowie muszą być z żelaza" miało natomiast w magiczny niemal sposób zaklinać przyszłość ${ }^{24}$.

Siła jednostek mogła zagwarantować pomyślne trwanie wspólnoty. Tymczasem bohatera jednego z opowiadań ze zbioru Wśród swoich, zdradzającego pewne podobieństwa z młodym wcieleniem narratora Opowieści o miłości i mroku, dręczyły zupełnie inne odczucia:

Nagle poczuł wstręt do samego siebie. Ten stan ducha ogarniał go często i z przeróżnych powodów. Potem nabrał obrzydzenia do tego wstrętu i w duchu drwił z siebie, używając słowa "pięknoduch”, tak jak przewodniczący określał czasami tych, których odstręcza konieczne okrucieństwo rewolucji 25 .

W opowieściach Oza "synowie z żelaza”, bohaterowie z kibuców, żołnierze bez lęku stający twarzą $\mathrm{w}$ twarz $\mathrm{z}$ wrogiem pozostają $\mathrm{w}$ sferze marzenia, mitu, projektu - koniecznego dla państwowotwórczej misji, lecz z założenia nieosiągalnego. Ważniejszy zatem za każdym razem okazuje się sygnowany jednostkowym, rzeczywistym zaangażowaniem, dobrowolny akces $\mathrm{w}$ zbiorowy wysiłek, którego sednem jest zdobywane $z$ trudem (i niejako warunkowo) przeświadczenie o słuszności dokonywanych wyborów.

Wymóg zachowania ciągłej gotowości do poświęcania się dla wspólnoty prowadzić może również do wytworzenia wiary w słuszność wszelkich podejmowanych $\mathrm{w}$ jej imieniu decyzji. $W$ książkowym reportażu pokazującym losy osadników z Zachodniego Brzegu, zatytułowanym Wnuki Jozuego, Paweł Smoleński pisał o "etosie stuletniego konfliktu”, uznawanym przez wielu Izraelczyków za zbiór pewników (oczywistych jakoby tak jak definicje punktu i prostej), a zarazem niepodważalnych wskazań do działania:

24 Zob. R. Pragier, Jest nowa saga!, „Twórczość” 2006, nr 3.

25 A. Oz, Wśród swoich, s. 57. 
Powstało (odrodziło się) państwo żydowskie, biedne, w dziwnych granicach, wystawione na arabskie ataki, ale jednak. Żydzi sami je wywalczyli. To był cud. Podobnie jak wszystko, co stało się później. Etos konfliktu podpowiada, że takie dziedzictwo zobowiązuje. Skoro umęczonym rolnikom i tym, którzy przetrwali obozy, a potem płynęli dziurawymi statkami do Hajfy i Tel Awiwu, udało się stworzyć państwo, należy to państwo rozszerzyć ${ }^{26}$.

Tym samym sankcja metafizyczna umożliwiała odnajdywanie ufundowań dla terytorialnej ekspansji - skoro trzeba było bronić przed najeźdźcą ziemi darowanej przez Najwyższego, można było również (w odwecie) poszerzać jej granice. Taka postawa, choć daleka od przekonań głoszonych przez samego pisarza (niestrudzenie orędującego za kompromisem w relacjach między wszystkimi stronami konfliktów na Bliskim Wschodzie), jawi się w tekstach Oza jako jedna z nieuchronnych konsekwencji projektowania tożsamości w oparciu o przywiązanie do ojczystej ziemi.

W zakończeniu Opowieści o miłości i mroku pojawia się wspomnienie ślubu pisarza w kibucu - wstąpił z żoną pod hupę wspartą nie jak kazał tamtejszy zwyczaj na dwóch widłach i dwóch karabinach, lecz na czterech widłach. Tym samym próbował pozostać wiernym zarazem wobec tradycji przodków, zwyczajów kibucu oraz własnej wizji dążenia do pokojowych rozwiązań. Projektem nadrzędnym w twórczości Oza wydaje się właśnie odtwarzanie skomplikowanych uwarunkowań indywidualnego wysiłku, który towarzyszy odnajdywaniu siebie i własnego miejsca na ziemi. Nieustannego trudu, który okazuje się konieczny, by pogodzić zobowiązania wobec wspólnoty z najgłębiej własnymi przekonaniami o tym, co jest słuszne.

Dążenie do wewnętrznej harmonii, pozostającej celem niezwykle trudnym do osiągnięcia, może okazać się także wartością samą w sobie, jeśli wiąże się z otwarciem na inność i poszanowaniem prawa do dokonywania odmiennych wyborów. Pisarz stwierdził u kresu życia: „Nie jest tu nudno. Izrael bywa, co prawda, denerwujący, czasami rodzi frustrację i złość, ale nieraz fascynuje i porywa. Tego, co zobaczyłem tu w czasie swojego życia, jest i znacznie mniej, i znacznie więcej, niż śniło się moim rodzicom i dziadkom" ${ }^{27}$. Skrajne emocje rodziły się zatem w miejscu, które, co prawda, nie stało się ucieleśnieniem marzeń przodków o mitycznym, idealnym raju na

26 P. Smoleński, Wnuki Jozuego, Wołowiec 2019, s. 293. Autor tak określa istotę wspólnotowych przekonań, łączących wielu osadników: „Bóg dał tę ziemię, tysiące lat temu zrobił Żydom prezent z Judei i Samarii, i to jest koniec dyskusji. Gdyby Bóg nie dał, wojna sześciodniowa musiałaby skończyć się klęską. Tymczasem Żydzi są w Judei i w Samarii, tak jak za czasów Dawida. Przywiązanie do ziemi to dobry uczynek, micwa, posłuszeństwo Najwyższemu" [tamże, s. 293].

27 A. Oz, Do fanatyków, s. 134. 
ziemi, ale niezmiennie pozostawało dla twórcy substancjalnym, realnym krajem ojczystym - wbrew zwątpieniu, niepewności i przesyconemu fatalizmem oglądowi żydowskiego losu.

\title{
Bibliografia
}

Ahmed Sara (2016), Wstyd w obliczu innych, przeł. J. Misun, „Teksty Drugie” 2016, nr 4, s. 194-212.

Akavia Miriam (2005), Moje powroty, Kraków: Wydawnictwo Literackie.

Bielik-Robson Agata (2005), Amos Oz: w poszukiwaniu mocy, Newsweek.pl, http:// www.newsweek.pl/europa/amos-oz-w-poszukiwaniu-mocy.

Bojarska Katarzyna (2013), Sztuka, która krzywdzi? Granice gestu krytycznego wobec bolesnej pamięci (a cenzura), „Konteksty. Antropologia Kultury. Etnografia. Sztuka” 2013, nr 3, s. 116-124.

Oz Amos (2005), Kiedy wypłaczesz wszystkie łzy, rozm. M. Jędrysik, „Gazeta Wyborcza", 27.05.2005, wyborcza.pl/1,75410,2733645.html.

Oz Amos (2010), Spokój doskonały, przeł. M. Sommer, Warszawa: Świat Książki.

Oz Amos (2016), Opowieśś o miłości i mroku, przeł. L. Kwiatkowski, Poznań: Rebis.

Oz Amos (2016), Wśród swoich, przeł. L. Kwiatkowski, Poznań: Rebis.

Oz Amos (2018), Do fanatyków. Trzy refleksje, przeł. L. Kwiatkowski, Poznań: Rebis.

Pragier Ruta (2006), Jest nowa saga! „Twórczość” nr 3.

Przymuszała Beata (2016), Smugi Zagłady. Emocjonalne i konwencjonalne aspekty tekstów ofiar i ich dzieci, Poznań: Wydawnictwo Naukowe UAM.

Smoleński Paweł (2019), Wnuki Jozuego, Wołowiec: Wydawnictwo Czarne.

Sobolewska Justyna (2010), Spokój między wojnami, „Polityka” nr 43, s. 94.

\section{This (One and Only) Place, Those (Most Important) Emotions: Remarks on the Works by Amos Oz}

\begin{abstract}
The article analyzes emotions in literature and their deep connection with the represented space. A good illustration of such interrelations is provided by the memoir of Amos Oz, A Tale about Love and Darkness (2002). The interpretation demonstrates that the relation between the personal experience (including family) and community values may shed light upon other questions such as the difficult past of the state of Israel, growing up into a wise patriotism and establishing real connections with the homeland.
\end{abstract}

Keywords: space, territory, emotions, homeland, family 